\title{
Recent Advances of Liquefied Petroleum Gas Sensors - From Environmental to Biotechnology Applications
}

\author{
Edward P.C. Lai* \\ Professor, Department of Chemistry, Carleton University, Ontario, Canada
}

Environmental biotechnology aims at accelerating the biodegradation of petroleum contaminated soils. It was demonstrated just six years ago that a consortium selected using the combined molecular-stepwise discriminated function analysis approach was more effective at degrading lubricant in contaminated sand than the single cultured isolates [1]. Agro-technical methods next involved tilling for maximum oxygen exposure, watering, nutrient application, biopile addition to attenuate the petroleum hydrocarbon (PHC) content, and phytoremediation treatments for cleanup [2]. In the experiments described, petroleum contamination of soils was simulated under field conditions, the remedial treatments were then utilized for cleanup. Analysis of soil parameters after a six-week study period showed an increase in total heterotrophic bacteria (THB) counts across all the treatments, with THB counts increasing with increment in soil nutrient level and initial concentration of the contaminant. Last year, "petroleum-eating mushrooms" broke new ground in environmental genomics [3]. A Petri dish containing crude petroleum would release a strong odor distinctive of the toxins that made up the fossil fuel. The researchers sprinkled mushroom spores over the Petri dish and let it sit for two weeks in an incubator, and surprise, the petroleum and its smell disappeared. Apparently, the mushrooms consumed the petroleum! Highly contaminated soil in the ground of an old refinery can be cleansed by following a simple recipe. Willow cuttings are planted so the roots dive into the ground and accumulate the degrading contaminants in the timber cells along with the bacteria. At the end of the season, the stems and leaves are burned to leave behind a handful of ashes.

Liquefied petroleum gases (LPG) are a constituent of crude oil or the condensate of natural gas fields. They are the $\mathrm{C} 3$ and $\mathrm{C} 4$ hydrocarbons, propane and butane respectively, which have the property of being gases at normal ambient temperature but can be liquefied and kept in the liquid state by quite moderate pressure [4]. The most successful exploitation of LPG has been its use as a fuel gas. Originally used in refineries for process heating, its value as a fuel was first realized before the Second World War when it was sold in small portable containers. From primarily domestic use this spread after the war to commercial and industrial utilization with bulk storage on-site. A standard life cycle assessment (LCA) methodology was used to compare the environmental impacts of different cooking fuels (charcoal, biogas and LPG) before a national policy is set up [5]. Global warming and human toxicity were the most significant overall environmental impacts in a Ghana study; charcoal and LPG made the largest contribution to these impacts respectively. LPG gave high impacts in three other categories of lesser significance - eutrophication, freshwater aquatic ecotoxicity, and terrestrial ecotoxicity potentials. Relatively, biogas had the lowest impact in five out of the seven categories investigated. From the global warming point of view, LPG had a slight overall advantage over the others. It was also the most favorable at the cooking stage, in terms of its effect on humans.

The unregulated formaldehyde and unburned methanol emissions of LPG/methanol engines were investigated by means of a single-cycle fuel injection strategy [6]. Using additional LPG resulted in reliable firing of the LPG/methanol engine at low ambient temperatures during a cold start. When the ambient temperature dropped, the mass ratio of injected LPG/methanol for reliable firing of the LPG/methanol engine increased rapidly. Dimethyl ether (DME) was evaluated as a potential fuel for solid oxide fuel cell (SOFC) systems designed for LPG [7]. Steam reforming of DME over a commercial reforming catalyst easily converted DME to reformate gas, indicating that both DME and LPG are reformed well. When evaluation of SOFC performance was carried out under steady power, similar performance level of DC electrical efficiency was realized when either DME or propane reformate gas was used at adequate steam-carbon ratio values. The results show that DME can be used as a fuel for an SOFC system designed for LPG without drastic alterations to the system.

Real-time monitoring of hazardous gases to signal any accidental leakages is of great importance to the safety concerns in industries and households. A near infrared (NIR) spectrometric method for screening analysis was aimed at discriminating samples with low and high propane content for the routine adjustment of burner settings in industrial applications [8]. A gas chromatograph (GC) was added to determine the propane content of the sample for reference purposes. The results of a principal component analysis, as well as soft independent modeling of class analogies, revealed that the samples were successfully discriminated with respect to propane content by using the NIR spectrum in the range $8100-8800 \mathrm{~cm}^{-1}$. In addition, by using linear discriminated analysis with variables selected by the successive projections algorithm, it was found that perfect discrimination can also be achieved by using only two wave numbers $\left(8215\right.$ and $\left.8324 \mathrm{~cm}^{-1}\right)$.

Highly sensitive gas sensors can be fabricated for detecting low concentrations of LPG, ideally using a simple and economical method. Platinum nanoparticles were deposited as a catalyst on the sensing medium of a metal oxide semiconductor [9]. The change in electrical resistance for varying concentrations of LPG was measured. Significant improvement in sensor response was observed after surface modification with zinc stannate $\left(\mathrm{Zn}_{2} \mathrm{SnO}_{4}\right)$ micro cubes on zinc oxide $(\mathrm{ZnO})$ nanorods. Nano crystalline $\mathrm{ZnO}$ thin films can be synthesized by a spray pyrolysis chemical deposition method for the detection of LPG [10]. The films comprised of a hexagonal wurtzite crystal structure with 32-39 nm crystallite sizes. Enhanced band gap of the film with heat treatment is a key factor for generating active sites for the sensing

*Corresponding author: Edward P.C. Lai, Professor, Department of Chemistry, Carleton University, Ontario, Canada, E-mail: edward_lai@carleton.ca

Received December 24, 2012; Accepted December 26, 2012; Published December 30, 2012

Citation: Lai EPC (2013) Recent Advances of Liquefied Petroleum Gas Sensors - From Environmental to Biotechnology Applications. J Pet Environ Biotechnol 4:e117. doi:10.4172/2157-7463.1000e117

Copyright: (c) 2013 Lai EPC. This is an open-access article distributed under the terms of the Creative Commons Attribution License, which permits unrestricted use, distribution, and reproduction in any medium, provided the original author and source are credited. 
Citation: Lai EPC (2013) Recent Advances of Liquefied Petroleum Gas Sensors - From Environmental to Biotechnology Applications. J Pet Environ Biotechnol 4:e117. doi:10.4172/2157-7463.1000e117

of gas species. The best sensitivity factors were obtained at an operating temperature of $255^{\circ} \mathrm{C}$ for LPG gas concentrations up to 1.2 volume $\%$ in air. Nano crystalline zinc titanate $\left(\mathrm{ZnTiO}_{3}\right)$ is another promising solidstate material that can be synthesized via a simple physicochemical method for LPG sensors [11]. X-ray diffraction analysis confirmed an average crystallite size of $19 \mathrm{~nm}$ with a hexagonal structure; its density and porosity were calculated to $4.2 \mathrm{~g} / \mathrm{cm}^{3}$ and $66 \%$ respectively. The resistance of a $\mathrm{ZnTiO}_{3}$ sensor varied for different volume \% of LPG. The response and recovery times were found to be $120 \mathrm{~s}$ and $200 \mathrm{~s}$ approximately. Ageing had minimal effect for the sensor response curve was reproducible after six months. Titanium oxide $\left(\mathrm{TiO}_{2}\right)$ powder can be obtained through ball milling and compressed into a pellet using a hydraulic press [12]. The resistance varied with exposure of the sensing pellet to LPG; the sensitivity was approximately 11 for 5 volume \% of LPG. Response and recovery times of the sensor were 100 and $250 \mathrm{~s}$. The sensor was reproducible within $91 \%$. Cobalt polyacrylamide (Co/PAAM) can be prepared by the formation of cobalt acrylamide complex, followed by frontal polymerization and pyrolysis of the polymer [13]. The crystallite size of the Co/PAAM was found approximately $6 \mathrm{~nm}$. Thick films of the metallo-polymers, made by screen printing technique, were investigated for LPG sensing. Larger variations in resistance were found for $\mathrm{Co} / \mathrm{PAAM}$ in comparison to $\mathrm{Co}\left(\mathrm{NO}_{3}\right)_{2} \cdot(\mathrm{AAM})_{4} \cdot 2 \mathrm{H}_{2} \mathrm{O}$; the maximum values of their sensitivities were 2.9 and $23.6 \mathrm{M} \Omega / \mathrm{s}$ respectively. The Co/PAAM sensor was found to be $96 \%$ reproducible after one month, showing both stability and reliability.

With all these advances of LPG sensors, will environmental biotechnology for soil decontamination be able to pick up speed at refinery sites? In the ambit of a recent project searching for appropriate biological approaches for recovering a refinery soil contaminated with PHC, the salt marsh plant Scirpus maritimushas demonstrated capability for remediation [14]. Additions of a non-ionic surfactant and a bioaugmentation product also brought about synergistic effects. Two remaining challenges to be tackled now are field conditions and weathered contamination.

\section{References}

1. Supaphol S, Panichsakpatana S, Trakulnaleamsai S, Tungkananuruk N Roughjanajirapa P, et al. (2006) Journal of Microbiological Methods 65: 432441.

2. Kogbara RB (2008) Electronic Journal of Biotechnology, volume 11 full text 4.

3. Lang BF, Hijri M (2011) Petroleum-eating mushrooms, Chemie.de, Germany.

4. Snow DA (2003) Plant Engineer's Reference Book (2ndedn.), ButterworthHeinemann, UK

5. Afrane G, Ntiamoah A (2011) Journal of Industrial Ecology 15: 539-549

6. Gong CM, Li J, Li JK, Li WX, Gao Q, et al. (2010) Fuel 90: 19-25.

7. Sato K, Tanaka A, Negishi A, Kato T (2012) Journal of Power Sources 217 : $37-42$.

8. Dantas HV, Barbosa MF, Nascimento ECL, Moreira PNT, Galvio RKH, et al. (2012) Talanta, Brazil.

9. Sivapunniyam A, Wiromrat N, Myint MTZ, Dutta J (2011) Sensors and Actuators B: Chemical 157: 232-239.

10. Gaikwad RS, Patil GR, Pawar BN, Mane RS, Han SH (2013) Sensors and Actuators A: Physical 189: 339-343.

11. Yadav BC, Yadav A, Singh S, Singh K (2013) Sensors and Actuators B Chemical 177: 605-611.

12. Yadav BC, Shukla T, Singh S, Yadav TP (2012) Titania Prepared by Ball Milling: Its Characterization and Application as Liquefied Petroleum Gas Sensor, Cornell University Library, USA

13. Singh S, Yadav BC, Tandon P, Singh M, Shukla A, et al. (2012) Sensors and Actuators B: Chemical 166-167: 281-291.

14. Couto MNPFS, Basto MCP, Vasconcelos MTSD (2012) Environmental Science and Pollution Research 19: 86-95. 